\title{
Regional differences in the testosterone to dihydrotestosterone ratio in the epididymis and vas deferens of adult mice
}

\author{
Ch. Jean-Faucher, M. Berger, C. Gallon, M. de Turckheim, G. Veyssiere and \\ Cl. Jean
}

\begin{abstract}
Physiologie Comparée et Endocrinologie, CNRS LA 360, Université Clermont II, Complexe Scientifique des Cézeaux. B.P. 45, 63170 Aubière, France
\end{abstract}

\begin{abstract}
Summary. The concentrations of testosterone and dihydrotestosterone (DHT) were measured in the testis and in different segments of the epididymis and vas deferens of adult mice. There were marked regional variations in the concentrations of testosterone and DHT from the testis to the caudal part of the vas deferens. In the testis, testosterone was the predominant androgen $(364 \pm 90 \mathrm{ng} / \mathrm{g})$ while DHT was weakly represented $(8 \pm 2 \mathrm{ng} / \mathrm{g})$. Qualitative and quantitative changes occurred in epididymis: DHT was the main steroid in the caput $(29.3 \pm 2.7 \mathrm{ng} / \mathrm{g})$ and corpus $(33.1 \pm 4.4 \mathrm{ng} / \mathrm{g})$ while testosterone and DHT were in similar quantities in the cauda $(18.6 \pm 2.6$ and $19 \cdot 0 \pm 2 \cdot 7 \mathrm{ng} / \mathrm{g}$, respectively). The proximal region of the vas deferens contained higher amounts $(71.4 \pm 8.0 \mathrm{ng} / \mathrm{g})$ of androgens (testosterone + DHT) than did the caput epididymidis $(39.1 \pm 3.3 \mathrm{ng} / \mathrm{g})$. Testosterone was the predominant androgen in each part of the vas deferens and its concentrations decreased from the proximal $(64.5 \pm 7.5 \mathrm{ng} / \mathrm{g})$ to the caudal $(26.9 \pm 4.3 \mathrm{ng} / \mathrm{g})$ region. Castration and section of the efferent ducts of the testis showed that the epididymis received testosterone essentially via the blood supply and that epididymal DHT was produced locally from circulating testosterone.
\end{abstract}

\section{Introduction}

The critical role of the epididymis in the maturation of spermatozoa is well established in mammals (Bedford, 1966; Orgebin-Crist, 1969; Hamilton, 1975). Anatomical and histological studies have shown that the organization, histology and fine structure vary from the proximal to the caudal segment of the epididymis (review in Hamilton, 1975). Various aspects of epididymal function, such as the maturation of spermatozoa (Bedford, 1975; Orgebin-Crist, Danzo \& Davies, 1975), secretion of specific proteins which attach to the sperm membrane during the fertilization process (Kohane, Cameo, Pineiro, Garberi \& Blaquier, 1980; Brooks \& Higgins, 1980; Brooks, 1983) and transport of the luminal content (Jaakkola, 1983), show regional variations. The gradual increase in the fertilizing ability of spermatozoa when passing through the epididymis has focussed interest on the epididymal steroid concentrations. The mouse epididymis shows ultrastructural features similar to those of steroidogenic tissues (Hamilton, 1971) and the enzymes necessary for the production of dihydrotestosterone and androstanediols from testosterone have been shown to exist in the epididymis of the mouse (Rastogi, Saxena \& Iela, 1976) and the rat (Scheer \& Robaire, 1980). A considerable degree of variation in the endogenous concentrations of steroids has been reported in the epididymis of rabbit (Frankel \& Eik-Nes, 1970), bull and boar (Aafjes \& Vreeburg, 1972), monkey (Larminat \& Blaquier, 1978), rat (Aafjes \& Vreeburg, 1972; Vreeburg, 1975; Kumari, Allag, Das \& Datta, 1980), dog (Boujard, Thomas \& Garnier, 1982), mouse (Jean-Faucher, Berger, de Turckheim, Veyssiere \& Jean, 1985a) and man (Leinonen, Hammond \& Vihko, 1980). 
In addition to its role in the transport of spermatozoa, the vas deferens has also been involved in sperm maturation and survival (Orgebin-Crist, 1969), metabolism of sex steroids (Hamilton \& Fawcett, 1970; Dupuy, Boulanger, Roberts, Bleau \& Chapdelaine, 1979; Kumari et al., 1980) and transfer of steroids into the prostatic circulation (Pierrepoint, Davies, Millington \& John, 1975). Except in rat (Aafjes \& Vreeburg, 1972; Vreeburg, 1975; Kumari et al., 1980; Nishihara \& Suzuki, 1980), dog (Boujard et al., 1982) and man (Leinonen et al., 1980), the regional distribution of steroids in the epididymis is poorly documented and no data are available for the vas deferens.

This study, therefore, was conducted in mice to determine the endogenous concentrations of testosterone and dihydrotestosterone in different regions of the epididymis and vas deferens. They were also measured after castration or section of the testicular efferent ductules in an attempt to determine the route by which androgens reach the epididymis and vas deferens.

\section{Materials and Methods}

Animals. Mice of the Swiss strain (CD-1 Charles River) were raised in the laboratory under identical conditions of temperature $\left(20 \pm 1^{\circ} \mathrm{C}\right)$, lighting (daylight) and nutrition (complete pelleted chow and water given freely). The 45 adult males ( 2 months) were decapitated and the organs (testes, epididymides, vasa deferentia) were immediately removed and placed on ice. The organs were carefully freed from surrounding connective tissue, blood and fat. The fluid of the epididymis and vas deferens was not extruded. The epididymis was divided into caput, corpus and cauda, and the vas deferens in three almost equal parts, i.e. proximal, medial and distal. Organs were stored at $-25^{\circ} \mathrm{C}$ until assayed. Before hormone assay the corresponding segments of the epididymis and vas deferens of 3 males were combined.

Castration and section of the efferent ducts of the testis were performed in 60-day-old males under light ether anaesthesia. The efferent ductules of the right testis were cut with great care not to interfere with the blood supply to the epididymis; the other side was left intact, so that contralateral organs served as untreated controls. Males were killed $24 \mathrm{~h}$ after the operation.

Radioimmunoassays. Testosterone and dihydrotestosterone (DHT) were measured by radioimmunoassay. The organs were homogenized in a solution of $N$-ethyl-maleimide $(5 \mathrm{mmol} / \mathrm{l})$ to inhibit the transformation of testosterone into DHT. Organ homogenates were then extracted with $6 \mathrm{ml}$ ethyl acetate-iso-octane $(3: 7, \mathrm{v} / \mathrm{v})$ after addition of tritiated testosterone (sp. act. $40 \mathrm{Ci} / \mathrm{mmol}$ ) and DHT (sp. act. $40 \mathrm{Ci} / \mathrm{mmol}$ ). The organic layer was washed with distilled water, dried in an airstream and redissolved in $1 \mathrm{ml}$ iso-octane for transfer to Celite columns. Celite column chromatography was employed to separate testosterone from DHT, and these two steroids from other cross-reacting steroids (Barberia \& Thorneycroft, 1974). Recovery of added radioactive standard was $74 \pm 10 \%$ (mean \pm s.d.) for testosterone and $60 \pm 10 \%$ for DHT. Radioimmunoassay was performed using an antibody (obtained in the laboratory) raised in rabbits against testosterone-3-O-carboxymethyl-oxime-bovine serum albumin at a final dilution of $1 / 45000$. After incubation overnight at $4^{\circ} \mathrm{C}$, free and bound fractions were separated by adding dextran-coated charcoal. Accuracy was determined by adding known amounts of testosterone and DHT (50, 100, $200,500 \mathrm{pg}$ ) to distilled water. Initial values were found with a precision of $4-14 \%$ for testosterone and $6-15 \%$ for DHT. The intra- and inter-assay variations were 6.0 and $6.1 \%$ for testosterone and 9.0 and $8.6 \%$ for DHT respectively. The sensitivity of the method, calculated according to the formula of Abraham (1974), was $45 \pm 10 \mathrm{pg}$ for testosterone and $55 \pm 12 \mathrm{pg}$ for DHT. Blank values were measured in spleen, an organ considered to be devoid of androgens. Testosterone and DHT were never detected in quantities of spleen equivalent to those of the organs used $(n=10)$. It was therefore concluded that other compounds such as fatty substances do not interfere with the direct tissue radioimmunoassay used. The major steroids cross-reacting in this system were testosterone $(100 \%)$ and DHT $(74 \%)$. Amongst the 17 other steroids studied, the cross-reactions of $5 \alpha$-androstane- $3 \beta, 17 \beta$-diol and $5 \alpha$-androstane- $3 \alpha, 17 \beta$-diol were $5 \%$ and $3 \%$ respectively; for the 
others it was $2 \%$. Androstanediols do not interfere with the assay since they were separated from testosterone and DHT by the Celite column chromatography (Barberia \& Thorneycroft, 1974).

Statistical evaluation was made by one-way analysis of variance and Duncan's new multiple range test. F-tests were calculated at the 0.05 level of significance. Paired Student's $t$ test was used when necessary. All data are expressed as the mean \pm s.e.m.

\section{Results}

\section{Regional androgen distribution in epididymis and vas deferens}

Since the ratio of testosterone to DHT differed with the organ considered, levels of both hormones were summed and named androgens (Fig. 1). Analysis of variance indicated that the androgen concentration varied significantly along the epididymis and vas deferens $(F=20 ; \mathrm{df}=5,84$; $P<0.001)$. The highest concentration was measured in the proximal part of the vas deferens, the lowest in the cauda epididymidis (Fig. 1). No consistent segmental distribution was apparent for epididymal androgen concentration but in the vas deferens it decreased significantly from the proximal to the caudal part of the organ $(\mathrm{F}=6.50 ; \mathrm{df}=2,42 ; P<0.001$; Duncan's new multiple range test). When testosterone and DHT were examined separately, their concentrations varied significantly from the caput epididymidis to the caudal vas deferens $(F=24$ for testosterone, 17 for DHT; df = 5,84; $P<0.001$ ). Analysis of variance showed that testosterone $(\mathrm{F}=4.6 ; \mathrm{df}=2,42 ; P<0.001)$ and DHT $(\mathrm{F}=5.9 ; \mathrm{df}=2,42 ; P<0.001)$ were differently located along the epididymis, with maximal concentrations of DHT in the caput and corpus, where this steroid was predominant, and similar quantities of testosterone and DHT in the cauda (Fig. 1).

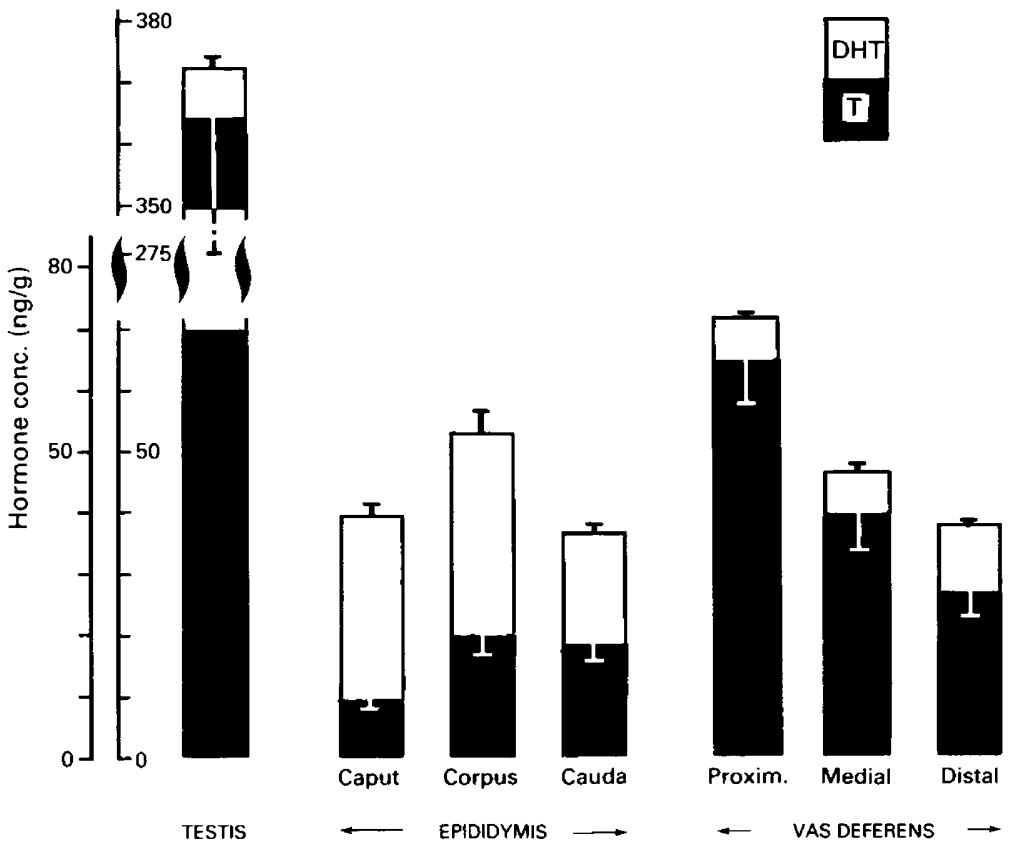

Fig. 1. Mean \pm s.e.m. concentrations of androgens (testosterone, $T$, and dihydrotestosterone, DHT) in the testis, caput, corpus and cauda epididymidis and in the proximal, medial or distal part of the vas deferens of adult male mice $(\mathrm{N}=15$ in each group). 
Testosterone was the predominant androgen in the vas deferens and its concentration decreased progressively from the proximal to the distal segment $(\mathrm{F}=9.0 ; \mathrm{df}=2,42 ; P<0.001)$; Duncan's new multiple range test). Low and similar DHT concentrations were detected along the vas deferens.

In the testis, testosterone was the predominant androgen ( $39 \mathrm{ng} /$ testis) while DHT was weakly represented $(0 \cdot 8 \mathrm{ng} /$ testis $)$. The testicular testosterone concentration $(364 \mathrm{ng} / \mathrm{g})$ was about 28 -fold that in the epididymis $(13 \mathrm{ng} / \mathrm{g}$ ) and 8 -fold that in the vas deferens $(46 \mathrm{ng} / \mathrm{g})$. Testicular DHT concentration was significantly lower than those measured in any part of the epididymis and similar to those determined in the vas deferens.

The testosterone/DHT ratio was very different in the three organs studied (Table 1). It increased from the caput to the cauda epididymidis where it was about one $(\mathrm{F}=11 ; \mathrm{df}=2,42 ; P<0.001)$. An abrupt increase occurred in the proximal part of the vas deferens and then the ratio progressively decreased until the caudal region $(\mathrm{F}=27 ; \mathrm{df}=2,42 ; P<0.001)$.

Table 1. Testosterone/DHT ratios in testis and in different segments of the epididymis and vas deferens of mice

\begin{tabular}{lccccccc}
\hline & \multicolumn{3}{c}{ Epididymis } & & & \multicolumn{3}{c}{ Vas deferens } \\
\cline { 2 - 3 } Testis & Caput & Corpus & Cauda & & Proximal & Medial & Distal \\
\hline $48 \pm 6$ & $0.35 \pm 0.04$ & $0.65 \pm 0.08$ & $0.99 \pm 0.13$ & & $9 \pm 0.6$ & $6 \pm 0.7$ & $3 \pm 0.2$ \\
\hline
\end{tabular}

Values are means \pm s.e.m. for 15 mice in each group.

\section{Effect of castration or section of the efferent ducts of the testis}

The efferent ducts of one testis were cut in 15 adult males which were killed $24 \mathrm{~h}$ later. The epididymal content of testosterone and DHT were then significantly $(0.02<P<0.05)$ lowered in the epididymis separated from the testis (paired Student's $t$ test). The androgen content of the ipsilateral vas deferens was not affected by the section of the efferent testicular ducts (Table 2). By $24 \mathrm{~h}$ after castration testosterone and DHT were undetectable or greatly reduced in the epididymis and vas deferens (Table 2).

Table 2. Testosterone (T) and DHT contents (pg/organ) in the epididymis and vas deferens of mice $24 \mathrm{~h}$ after bilateral castration or section of the efferent ducts of one testis

\begin{tabular}{|c|c|c|c|c|c|c|c|c|}
\hline \multirow[b]{2}{*}{ Treatment } & \multicolumn{4}{|c|}{ Epididymis } & \multicolumn{4}{|c|}{ Vas deferens } \\
\hline & $\begin{array}{l}\text { Weight } \\
\text { (mg) }\end{array}$ & $T$ & DHT & $\mathrm{T}+\mathrm{DHT}$ & $\begin{array}{l}\text { Weight } \\
\text { (mg) }\end{array}$ & $\mathbf{T}$ & DHT & $\mathrm{T}+\mathrm{DHT}$ \\
\hline $\begin{array}{l}\text { Control } \\
\text { Section of the }\end{array}$ & $49 \pm 2$ & $370 \pm 70$ & $1285 \pm 287$ & $1655 \pm 323$ & $15 \pm 0 \cdot 2$ & $628 \pm 118$ & $116 \pm 23$ & $746 \pm 90$ \\
\hline $\begin{array}{l}\text { ducts } \\
\text { Castration }\end{array}$ & $\begin{array}{l}51 \pm 2 \\
48 \pm 3\end{array}$ & $\begin{array}{l}310 \pm 60^{*} \\
\mathrm{ND}\end{array}$ & $\begin{array}{c}1086 \pm 228^{*} \\
176 \pm 25\end{array}$ & $\begin{array}{c}1385 \pm 249^{*} \\
176 \pm 25\end{array}$ & $\begin{array}{l}15 \pm 0.3 \\
14 \pm 0.6\end{array}$ & $\begin{array}{c}614 \pm 74 \\
\mathrm{ND}\end{array}$ & $\begin{array}{c}130 \pm 37 \\
\mathrm{ND}\end{array}$ & $\begin{array}{c}742 \pm 80 \\
\text { ND }\end{array}$ \\
\hline
\end{tabular}

Values are means \pm s.e.m. for 15 mice in each group (10 in the castration group).

$\mathrm{ND}=$ not detectabile.

$* 0.02<P<0.05$ compared with control group (paired Student's $t$ test). 


\section{Discussion}

As in other species, including the rat (Vreeburg \& Aafjes, 1971; Pujol, Bayard, Louvet \& Boulard, 1976; Purvis \& Hansson, 1978; Nishihara \& Suzuki, 1980; Kumari et al., 1980), bull and boar (Aafjes \& Vreeburg, 1972), dog (Boujard et al., 1982) and man (Purvis, Calandra, Sander \& Hansson, 1978; Leinonen et al., 1980), the epididymis of the mouse contains high levels of androgens. Furthermore, high concentrations were also measured in the vas deferens. The androgen concentrations (testosterone + DHT) measured in the caput epididymidis of the mouse $(39 \cdot 1 \pm 3 \cdot 3 \mathrm{ng} / \mathrm{g}$ ) were in the range of those determined in rat $(25 \mathrm{ng} / \mathrm{g}$ : Pujol et al., 1976; $180 \mathrm{ng} / \mathrm{g}$; Kumari et al., 1980) and man (47 ng/g: Leinonen et al., 1980; $59 \mathrm{ng} / \mathrm{g}$ : Purvis et al., 1978) and higher than those reported in bull and boar (10-17 ng/g: Aafjes \& Vreeburg, 1972). There were marked regional variations in the levels of testosterone and DHT from the testis to the caudal part of the vas deferens. When the androgen concentrations in the testis and caput epididymidis are compared, it is evident that testosterone values are drastically reduced in the latter while those of DHT are significantly higher than in the testis. Similar observations have also been reported for rats (Pujol et al., 1976; Purvis \& Hansson, 1978), bulls and boars (Aafjes \& Vreeburg, 1972) and dogs (Boujard et al., 1982). In the rat a significant downhill concentration gradient exists between testosterone concentrations in testicular and epididymal fluids, and the highest concentrations of DHT were seen in intraluminal epididymal fluids (Turner, et al., 1984). Qualitative and quantitative changes in androgen concentrations occurred along the epididymis: DHT was the main steroid in the caput and corpus while in the cauda testosterone and DHT were present in similar quantities.

It appears from the present results that the vas deferens, particularly the proximal region, contains androgens in higher amounts than do the caput epididymidis and other sex accessory glands such as the seminal vesicle and preputial gland (Jean-Faucher et al., 1985b). Quantitative but not qualitative changes occurred in androgen concentrations from the proximal to the distal vas deferens. Testosterone was the predominant androgen in all segments of the vas but its concentration progressively decreased towards the distal region while DHT stayed at low but constant levels. This suggests that, in the vas deferens, as in organs other than skin and reproductive tract (Bardin \& Catterall, 1981), testosterone rather than DHT may be the major intracellularly active androgen.

The epididymis receives androgens by two routes: the blood stream and testicular fluid (Cooper \& Waites, 1974; Pujol et al., 1976). In mice, the amount of testosterone reaching the epididymis by way of the efferent ducts seems to be small since the epididymal content of testosterone was lowered to about $15 \%$ after acute section and was undetectable after castration. The results of castration also showed that testosterone reaches the vas deferens only by way of the general circulation.

The ability of epididymis and vas deferens to synthesize testosterone from cholesterol or acetate, demonstrated in vitro (Hamilton \& Fawcett, 1970), is probably very low in physiological conditions, as shown by the results of castration. Since DHT is undetectable in the plasma of adult mice (Jean-Faucher et al., 1982) and since testicular DHT cannot be the sole source of this steroid for the epididymis (present results), the high concentrations of DHT measured in this organ presumably reflect a local production. The variations of the testosterone/DHT ratio along the epididymis and vas deferens may therefore be due to different activities of enzymes such as $5 \alpha$-reductase (Djoseland, Hansson \& Haugen, 1973; Robaire, Ewing, Zirkin \& Irby, 1977) and/or to segmental distribution of binding proteins such as ABP and receptors, as has been recently shown in the epididymis of the rat (Pujol \& Bayard, 1979) and ram (Carreau, Drosdowsky \& Courot, 1984a, b).

We thank S. Tournadre for technical assistance. 


\section{References}

Aafjes, J.H. \& Vreeburg, J.T.M. (1972) Distribution of $5 a$-dihydrotestosterone in the epididymis of bull and boar and its concentration in rat epididymis after ligation of efferent testicular ducts, castration and unilateral gonadectomy. J. Endocr. 53, 85-93.

Abraham, G.E. (1974) Radioimmunoassay of steroids in biological materials. Acta endocr., Copenh., Suppl. $183,7-42$.

Barberia, J.M. \& Thorneycroft, I.H. (1974) Simultaneous radioimmunoassay of testosterone and dihydrotestosterone. Steroids 23, 757-766.

Bardin, C.W. \& Catterall, J.F. (1981) Testosterone: a major determinant of extra-genital sexual dimorphism. Science N.Y. 211, 1285-1294.

Bedford, J.M. (1966) Development of the fertilizing ability of spermatozoa in the epididymis of the rabbit. J. exp. Zool. 163, 319-330.

Bedford, J.M. (1975) Maturation, transport and fate of spermatozoa in the epididymis. In Handbook of Physiology, Section 7, Vol. V, pp. 307-317. Eds D. W. Hamilton \& R. O. Greep. Am. Physiol. Soc., Washington, D.C.

Boujard, D., Thomas, D. \& Garnier, D.H. (1982) Regional distribution of steroids in the dog epididymis. Reprod. Nutr. Develop. 22, 931-939.

Brooks, D.E. (1983) Effect of androgens on protein synthesis and secretion in various regions of the rat epididymis, as analysed by two-dimensional gel electrophoresis. Molec. cell. Endocr. 29, 255-270.

Brooks, D.E. \& Higgins, S.J. (1980) Characterization and androgen-dependance of proteins associated with luminal fluid and spermatozoa in the rat epididymis. J. Reprod. Fert. 59, 363-375.

Carreau, S., Drosdowsky, M.A. \& Courot, M. (1984a) Androgen-binding proteins in sheep epididymis: characterization of a cytoplasmic androgen receptor in the ram epididymis. J. Endocr. 103, 273-279.

Carreau, S., Drosdowsky, M.A. \& Courot, M. (1984b) Androgen-binding proteins in sheep epididymis: age-related effects on androgen-binding protein, cytosolic androgen receptor and testosterone concentrations. Correlations with histological studies. $J$. Endocr. 103, 281-286.

Cooper, T.G. \& Waites, G.M.H. (1974) Testosterone in rete testis fluid and blood of rams and rats. J. Endocr. 62, 619-629.

Djoseland, O., Hansson, V. \& Haugen, H.N. (1973) Androgen metabolism by rat epididymis. I. Metabolic conversion of ${ }^{3} \mathrm{H}$-testosterone in vivo. Steroids 21, 773-783.

Dupuy, G.M., Boulanger, P., Roberts, K.D., Bleau, G. \& Chapdelaine, A. (1979) Metabolism of sex steroids in the human and canine vas deferens. Endocrinology 104, 1553-1558.

Frankel, A.I. \& Eik-Nes, K.B. (1970) Testosterone and dehydroepiandrosterone in the epididymis of the rabbit. J. Reprod. Fert. 23, 441-445.

Hamilton, D.W. (1971) Steroid function in the mammalian epididymis. J. Reprod. Fert. 13, 89-97.

Hamilton, D.W. (1975) Structure and function of the epithelium lining the ductuli efferentes, ductus epididymis, and ductus deferens in the rat. In
Handbook of Physiology, Section 7, Vol. V, pp. 259-302. Eds D. W. Hamilton \& R. O. Greep. Am. Physiol. Soc., Washington, D.C.

Hamilton, D.W. \& Fawcett, D.W. (1970) In vitro synthesis of cholesterol and testosterone from acetate by rat epididymis and vas deferens. Proc. Soc. exp. Biol. Med. 133, 693-695.

Jaakkola, U.M. (1983) Regional variations in transport of the luminal contents of the rat epididymis in vivo. J. Reprod. Fert. 68, 465-470.

Jean-Faucher, Ch., Berger, M., de Turckheim, M., Veyssiere, G. \& Jean Cl. (1982) Plasma and testicular testosterone and dihydrotestosterone in mice: effect of age and HCG stimulation. IRCS Med. Sci. 11, 26-27.

Jean-Faucher, Ch., Berger, M., de Turckheim, M., Veyssiere, G. \& Jean, Cl. (1985a) Testosterone and dihydrotestosterone levels in epididymis, vas deferens and preputial gland of mice during sexual maturation. Int. J. Androl. 8, 4457.

Jean-Faucher, Ch., Berger, M., de Turckheim, M., Veyssiere, G. \& Jean, Cl. (1985b) Testosterone and dihydrotestosterone levels in epididymis, vas deferens, seminal vesicle and preputial gland of mice after hCG injection. J. Steroid Biochem. 23, 201-205.

Kohane, A.C., Cameo, M.S., Pineiro, L., Garberi, J.C. \& Blaquier, J.A. (1980) Distribution and site of production of specific proteins in the rat epididymis. Biol. Reprod. 23, 181-187.

Kumari, G.I., Allag, I.S., Das, R.P. \& Datta, J.K. (1980) Regional differences in steroidogenesis and hormone levels in the epididymis and vas deferens of adult rats. Int. J. Androl. 3, 267-281.

Larminat, M.A. de \& Blaquier, J.A. (1978) Androgen concentration and partial characterization of $5 \alpha$-reductase in the epididymis of the rhesus monkey. Steroids 31, 129-138.

Leinonen, P., Hammond, G.L. \& Vihko, R. (1980) Testosterone and some of its precursors and metabolites in the human epididymis. J. clin. Endocr. Metab. 51, 423-428.

Nishihara, M. \& Suzuki, Y. (1980) Androgen distribution in male rats. Endocrinol. japon. 27, 637-642.

Orgebin-Crist, M.C. (1969) Studies on the function of the epididymis. Biol. Reprod., Suppl. 1, 155-175.

Orgebin-Crist, M.C., Danzo, B. \& Davies, J. (1975) Endocrine control of the development and maintenance of sperm fertilizing ability in the epididymis. In Handbook of Physiology, Section 7, Vol. V, pp. 319-338. Eds D. W. Hamilton \& R. O. Greep. Am. Physiol. Soc., Washington D.C.

Pierrepoint, C.G., Davies, P., Millington, D. \& John, B.M. (1975) Evidence that the deferential vein acts as a local transport system for androgen in the dog and the rat. J. Reprod. Fert. 43, 293-303.

Pujol, A. \& Bayard, F. (1979) Androgen receptors in the rat epididymis and their hormonal control. J. Reprod. Fert. 56, 217-222.

Pujol, A., Bayard, F., Louvet, J.P. \& Boulard, C. (1976) Testosterone and dihydrotestosterone concentrations in plasma, epididymal tissues, and seminal fluid of adult rats. Endocrinology 98, 111-113. 
Purvis, K. \& Hansson, V. (1978) Androgens and androgen-binding protein in the rat epididymis. $J$. Reprod. Fert. 52, 59-63.

Purvis, K., Calandra, R., Sander, S. \& Hansson, V. (1978) Androgen binding proteins and androgen levels in the human testis and epididymis. Int. J. Androl. 7, 531-548.

Rastogi, R.K., Saxena, P.K. \& Iela, L. (1976) Histochemical localization of some hydroxysteroid dehydrogenases in the mouse epididymis. Hormone Res. 7, 43-48.

Robaire, B., Ewing, L.L., Zirkin, B.R. \& Irby, D.C. (1977) $\Delta^{4}-5 \alpha$-reductase and $3 \alpha$-hydroxysteroid dehydrogenase in the rat epididymis. Endocrinology 101, 1379-1390.

Scheer, H. \& Robaire, B. (1980) Steroid $\Delta^{4}$-5 $\alpha$-reductase and $3 \alpha$-hydroxysteroid dehydrogenase in the rat epididymis during development. Endocrinology 107, 948-953.
Turner, T.T., Jones, C.E., Howards, S.S., Ewing, L.L., Zegeye, B. \& Gunsalus, G.L. (1984) On the androgen microenvironment of maturing spermatozoa. Endocrinology 115, 1925-1932.

Vreeburg, J.T.M. (1975) Distribution of testosterone and $5 \alpha$-dihydro-testosterone in rat epididymis and their concentrations in efferent duct fluid. J. Endocr. 67, 203-210.

Vreeburg, J.T.M. \& Aafjes, J.H. (1971) Dihydrotestosterone (5 $\alpha$-androstan-17 $\beta$-ol-3-one) in the epididymis of rats. In Current Problems in Fertility, pp. 203-206. Eds A. Ingelman-Sundberg \& N. O. Lunell. Plenum Press, New York.

Received 9 April 1985 